\title{
La conformación popular de la religiosidad sevillana en el Barroco y la llustración: la importancia del vecindario
}

\author{
Carlos josé Romero mensaque
}

\begin{abstract}
RESUMEN
En este artículo se analiza la importancia del entorno humano que rodea la sede de una hermandad, el

barrio o vecindario, no sólo como elemento activador de su vida, sino sobretodo como generador de ese fenómeno de religiosidad popular que hizo posible primero la devoción a una imagen o práctica concreta de piedad,

posteriormente la agrupación de

devotos y finalmente la propia hermandad en la ciudad de Sevilla durante los años finales del siglo XVIII.

Voy a circunscribir esta tesis a un grupo de hermandades muy caracteristicas y que he estudiado a fondo, que son las corporaciones del

Rosario radicadas en sedes extraparroquiales, bien en retablos públicos en plena calle, bien en modestas capillas erigidas por los propios hermanos

\section{ABSTRACT}

In this article the importance of the human environment is analyzed that surrounds the headquarters of a fraternity, the district or neighborhood, I don't only eat element activator of its life, but overalls like generator of that phenomenon of popular religiosity that made possible first the devotion to an image or concrete practice of pity, later on the grouping of devote and finally the own fraternity in Seville during the later XVIII century. I will bound this thesis to a group of very characteristic fraternities and that I have thoroughly studied that are the Rosario's corporations resided in chapels out of parish, well in public altarpieces in full street, well in modest chapels erected by the own siblings
\end{abstract}




\section{INTRODUCCIÓN}

En los estudios de religiosidad popular, no resulta fácil para el historiador constatar hipótesis de trabajo ni tratar de generalizar conclusiones por cuanto es evidente la tremenda complejidad del fenómeno así como su carácter particularista y en parte heterodoxo respecto a los cánones establecidos por la Jerarquía Eclesiástica. En el caso sevillano, estos rasgos aparecen todavía más patentes y es necesario circunscribir áreas de estudio muy determinadas para establecer inductivamente unos rasgos definitorios que posibiliten un acercamiento real a fenómenos de religiosidad popular desde un conocimiento no ya objetivo de unos elementos concretos que se repiten con cierta similitud, sino sobretodo explicitador de una marcada personalidad que dimana de motivaciones concretas, subjetivas, particulares de las gentes que generan con variable espontaneidad los fenómenos.

La Sevilla del Barroco y la llustración nos presenta una realidad coherente y estructural en el campo de la religiosidad popular que es el llamado periodo barroco, que puede alcanzar en la ciudad hasta el último tercio del siglo xVIII y una tremenda coyuntura que se desarrolla en gran parte del siglo $X I X{ }^{1}$ en la que se ponen en crisis una serie de conceptos absolutos y elementos básicos de la religiosidad barroca que evolucionan y se transforman paulatinamente conforme a las nuevas circunstancias socioeconómicas y políticas y las mentalidades que van surgiendo y patentizando la dimensión religiosa y transcendente como una opción ciertamente mayoritaria, pero que en modo alguno se constituye en superestructura vital como el régimen de cristiandad barroca ${ }^{2}$, que aunque resquebrajado por las contradicciones y las hipocresías era asumido mentalmente y constituía en la práctica concreta de la religiosidad popular un todo envolvente que limitaba el horizonte mental y a la vez potenciaba la espontaneidad devocional a grados de protagonismo popular que rebasaban con creces la eclesialidad oficial, que era relegada de manera muy preocupante para la Jerarquía.

El campo concreto de mis estudios sobre religiosidad popular se centra precisamente en esta época de la Modernidad sevillana y particularmente en un ámbito relativamente poco conocido por la escasa importancia a la

1 Cfr. Romero Mensaque, Carlos J., "Sociedad y religiosidad popular en la Sevilla de la llustración", en Del Antiguo al Nuevo Régimen Liberal. Sevilla, UNED, 1990.

2 Cfr.Dominguez Ortiz, Antonio, De Carlos V a la Paz de los Pirineos. Historia de España III. Barcelona, Grijalbo, 1973, pp 211-226.

La tesis de esa frontera inexistente entre los ámbitos civil y eclesiástico es básica para la sociedad del Barroco. 
que ha quedado relegado en la actualidad, pero que en los siglos XVII $y$ XVIII constituyó el elemento básico y configurador de la religiosidad hispalense, siendo un auténtico paradigma de la asunción popular del protagonismo indicado en los ámbitos devocionales. Me refiero al campo de las congregaciones y hermandades de Gloria, mucho más vasto e integrador de las masas populares que las corporaciones penitenciales limitadas prácticamente a sus salidas procesionales en los días de la Semana Santa $y$, por supuesto, que las muy diversas asociaciones dependientes directamente de la estructura parroquial o de órdenes religiosas que marcaban la que pudiéramos denominar religiosidad "oficial".

Ciertamente supone esta distinción entre religiosidad popular y religiosidad "oficial" una cuestión metodológica, pero que responde a una realidad contrastada, aunque con notables excepciones.

La religiosidad popular es controlada por la Jerarquía a través de las parroquias y la propia curia diocesana, pero goza de una indudable autonomía que se confirma jurídicamente con la erección de las hermandades, surgidas para preservar una devoción o una práctica concreta de religiosidad y como cauce canónico de control, pero que de hecho la fundación parte del pueblo y su gobierno y administración es ejercido por los cofrades sin más injerencias que las estrictamente juridicas y expresadas por las Reglas, que son de obligada aprobación de la Mitra.

La religiosidad «oficial» depende directamente y de modo efectivo de la Jerarquía secular o regular y surge a su iniciativa concreta $y$, por tanto, el control es mucho más claro y la participación activa del pueblo se halla más limitada, aunque es constatable su existencia sobretodo dentro del ámbito ya reseñado de las asociaciones o cofradías surgidas por iniciativa del clero $o$, en todo caso, con su dirección. Y no deja de ser sintomático que estas asociaciones gocen menos del favor popular que las anteriores y que muchas, paulatinamente, van evolucionando hasta constituirse en hermandades diocesanas autónomas, por necesidades de la propia pastoral de la parroquia que comprende y asume la autonomía de estas hermandades y es entonces cuando adquieren el arraigo popular y, paradójicamente también, cuando más sirven de cauce eclesial ${ }^{3}$.

\footnotetext{
3 Es el caso, por ejemplo, de la Hermandad del Rosario de Santa Catalina, que es erigida para estructurar una ingente devoción rosariana en la parroquia con una dependencia absoluta de la corporación de la corporación sacramental de la parroquia, que no genera más que conflictos hasta que se separa jurídicamente y se constituye en hermandad autónoma. Cfr. mi artículo, «Hermandad, parroquia y religiosidad popular en Sevilla. La Hermandad del Rosario de Santa Catalina en el siglo XVIII" en Guía de los archivos de cofradias de Sevilla. Otros estudios. Sevilla, CEIRA, 1991.
} 
En otras ocasiones, sin modificar sus estructuras jurídicas, la religiosidad "oficial» trata de adaptarse a la religiosidad popular en sus elementos devocionales en su afán de integración en el pueblo. Es el caso, por ejemplo, de los padres dominicos que introdujeron la devoción rosariana en Sevilla, fueron sus máximos propagadores, instituyeron diversas cofradias y generaron la explosión de los Rosarios Públicos, fenómeno que constituyó el elemento paradigmático de la religiosidad barroca. Posteriormente sus iniciativas pasaron a ser asumidas por el pueblo como suyas y quedaron sólo sus cofradías conventuales, con un progresivo desarraigo popular frente a las hermandades diocesanas, por lo que nada tiene de extraño que, por iniciativa del propio Prior de San Pablo, la Primitiva Cofradía del Rosario de Sevilla modifique la vestimenta de la imagen titular a la moda imperante de las hermandades de Gloria y adapte igualmente su aspecto procesional ${ }^{4}$.

La Hermandad diocesana, dependiente del Ordinario secular, se constituye, pues, como el ente que, por un lado canoniza una devoción o práctica concreta surgida espontáneamente en el pueblo -o asumida con el tiempo como tal- y por otro, integra a éste en el organigrama eclesial. Ciertamente es una institución creada por la Jerarquía desde el punto de vista jurídico con el objetivo de establecer un cierto control de la religiosidad popular, pero en el caso que nos ocupa, la Hermandad es igualmente asumida por el pueblo como algo propio y consustancial a su religiosidad, con lo cual, ordinariamente, no se va a considerar una institución ajena. Si a esto se le añade su amplia autonomía práctica, la hace todavía más cercana.

En este artículo quiero analizar la importancia del entorno humano que rodea la sede de una hermandad, el barrio o vecindario, no sólo como elemento activador de su vida, sino sobrelodo como generador de ese fenómeno de religiosidad popular que hizo posible primero la agrupación de devotos y posteriormente la propia hermandad. Voy a circunscribir esta tesis a un grupo de hermandades muy características y que he estudiado a fondo, que son las corporaciones del Rosario radicadas en sedes extraparroquiales, bien en retablos públicos en plena calle, bien en modestas capillas erigidas por los propios hermanos.

Estas corporaciones surgen a fines del siglo XVII en torno al fenómeno de los Rosarios Públicos, que constituyó un acontecimiento singular en la ciudad generando un tipo de religiosidad tremendamente original -aunque

4 Cfr. Romero Mensaque, Carlos J., "Religiosidad oficial en la Sevilla del Barroco. La Primitiva Cofradia del Rosario en el siglo XVII", en Las fiestas de Sevilla en el siglo XV. Otros estudios. Sevilla, CEIRA, 1992. 
existen antecedentes- que al sustrato existente añade dos características esenciales: El dinamismo y la cotidianidad. Frente a una religión estática de templos y capillas, los elementos sagrados salen al encuentro del hombre por calles y plazas y esto todos los días a muy diversas horas de la tarde y noche y posteriormente de la mañana ${ }^{5}$.

Se quiera o no, este fenómeno añade al régimen de cristiandad barroco una nueva personalidad militante. Lo importante, no obstante, está en el protagonismo del pueblo, superando primigenias tutelas. Pero junto a lo expuesto, hay que añadir un aspecto importante que hace que este protagonismo aumente y el concepto de hermandad tienda cada vez más a unirse con el de su entorno vital: el barrio, la vecindad y es que el fenómeno rosariano es en un primer momento un movimiento oracional carente de imágenes concretas de culto, por lo que, aunque se fundamentaba en una devoción mariana, ésta se abstraía y lo importante era la práctica de oración en común. De esta manera, la religión dejaba de tener un ámbito clerical en exclusiva para ser patrimonio del pueblo que sentía presente a Dios en aquellos grupos de hombres y mujeres, sus vecinos que cantaban por las calles. El Rosario se convirtió en una práctica simple y accesible en la que el pueblo encontró un modo de comunicarse con la Transcendencia con sus propias palabras y desde su propia vida, de su cotidianidad, con su propia personalidad. En esto influyó el clima misional creado en Sevilla tras la terrible Pestilencia de 1649 en la que los predicadores hicieron ver al pueblo aquel mal como un castigo divino que era preciso reparar para reconciliarse con Dios. En este sentido, ciertos predicadores fomentaron la práctica del Rosario como el jesuita Tirso González y, sobretodo, el dominico Ulloa, que con su mejor buena fe llegó a hacer pensar a cierto sector del pueblo en una práctica absolutización de este rezo como medio de salvación casi equiparándolo a los sacramentos ${ }^{6}$.

\footnotetext{
5 Sobre este fenómeno, vid. mi artículo publicado en esta misma Revista, "Cotidianidad, dinamismo y espontaneidad en la religiosidad popular: el fenómeno de los Rosarios públicos en la Sevilla del Barroco", t. 11, 1998, pp. 215-238.

6 Las predicaciones de fray Pedro de Santa María de Ulloa, dominico de San Pablo, concitaron durante los tres años que permaneció en Sevilla hasta su muerte (1690) una tremenda expectación que hacia llenar permanentemente la iglesia del cenobio en las tres alocuciones diarias centradas en los correspondientes Misterios del Rosario, que rezaba y comentaba ampliamente. Gozó de un carisma tal entre los sevillanos que, a su muerte, fue despedido en olor de santidad y poco después salieron los primeros Rosarios públicos propiamente dichos en un marco devocional exacerbado, que pronto contagió a toda la ciudad.

Sobre las controversias derivadas de las predicaciones de Ulloa y la polémica creada en la que se vio implicada la propia Orden en un conflicto con otras y en las que el propio Ulloa intervino defendiéndose de acusaciones de heterodoxia infundadas, vid mi artículo: El fenómeno rosariano como expresión de religiosidad popular en la Sevilla del Barroco, en La Religiosidad Popular. Barcelona, 1987, t. 2, pp. 540-553.
} 
Esta auténtica explosión rosariana comienza a declinar en el último tercio del siglo XVIII, sufre profundas transformaciones en el siglo XIX surgiendo los denominados de Aurora, pero con mucha menos incidencia popular, decayendo totalmente en la segunda mitad de este siglo, al evolucionar el instituto a la devoción mariana concretada en la imagen titular de cada hermandad rosariana, desapareciendo así la cotidianidad y el dinamismo propio del fenómeno.

Así pues, puede irse percibiendo como el Rosario va a ser en estas fechas un auténtico paradigma de la iniciativa vecinal que genera una religiosidad popular propia, genuina y espontánea que es símbolo de la personalidad de un barrio. En este sentido, la iniciativa del barrio es la que crea una primitiva congregación de devotos y quien luego consolida una Hermandad, pero una hermandad que nace en plena vía pública, al amparo de un breve retablo callejero construido por los vecinos y que se considera patrimonio de todos. De estas raíces sí cabe plenamente afirmar la identificación Hermandad-Barrio dentro del ámbito de la religiosidad popular, pero - como se verá- esta unión no es en modo alguno permanente, sino determinada a un periodo de tiempo equivalente a la estabilidad de las circunstancias que la motivaron.

Ciertamente el fenómeno rosariano no es exclusivo a la hora de constatar la identificación Hermandad-Barrio en el ámbito de la religiosidad barroca, pero sin duda supone uno de sus elementos más significativos.

A continuación voy a establecer las características fundamentales de esta relación entre el barrio, la religiosidad y la hermandad a través de datos significativos que pretenden facilitar la comprensión de mi tesis fundamental en este artículo, el papel activo del barrio en la generación de la religiosidad popular.

\section{EL BARRIO, CUNA Y SEDE DE LA RELIGIOSIDAD}

En las hermandades extraparroquiales que nos sirven de base para nuestro estudio, la fundación de la primera congregación que surge en torno a la devoción rosariana se desarrolla en el espacio concreto de un retablo callejero dedicado a la Virgen y construido por los propios vecinos. Así, en el caso de la Cesteria, se situaba aproximadamente en la calle Santas Patrorias. En la Costanilla del Salvador sobre un arco en la entrada a la actual plaza del Pan. En el Rosario de los Humeros, en el muro del vecino convento de San Laureano. En la Resolana se aprovecha un pequeño humilladero y, por último, en el caso de la corporación 
rosariana de la Virgen de Europa, un retablo sito en la plaza del mismo nombre ${ }^{7}$.

En estos retablos situados en plena vía pública se reunían al toque de oraciones los vecinos para organizar el cortejo del Santo Rosario y fijar las estaciones e itinerario.

Mientras el ejercicio rosariano tenía su sede en estos retablos efímeros, los vecinos se constituían en el único patrimonio y sostén de estos cortejos espontáneos e incluso cuando se llegaban a constituir en congregaciones o hermandades, a pesar de contar con un respaldo legal, un patrimonio y una administración propia puesto que los cofrades no sólo seguían siendo vecinos, sino que la cotidianidad y los esquemas abiertos del gobierno de la corporación hacian posible la participación efectiva del vecindario, independientemente de su pertenencia formal o no a la corporación.

En este sentido, lo que la hermandad aportó fue la consolidación de la práctica rosariana, la adquisición de un patrimonio básico como el Simpecado o faroles, una mejor organización, la dirección espiritual y reconocimiento por la Iglesia así como un incipiente culto en torno a la Virgen que genera una devoción concreta.

Paulatinamente la sede iba sufriendo mejoras y ampliaciones, aunque manteniéndose en su lugar primigenio y, por tanto, en contacto diario y abierto con el barrio aunque en el caso del Rosario de los Humeros y la Resolana, la Hermandad erige una capilla de fábrica mediante cuestación del vecindario, lo que, por un lado significa una consolidación importante de este fenómeno de religiosidad y también de la devoción a una imagen, que es objeto de un culto diario y, por otro, un cierto desarraigo a pesar de que el ejercicio rosariano se mantenía por las calles de la vecindad ${ }^{8}$.

7 Vid. asimismo mi tesis de licenciatura La Muy llustre Hermandad de Nuestra Señora de Europa de la ciudad de Sevilla. Sevilla, Consejo General de Cofradias, 1983.

Se trata de una humilde hermandad fundada a fines del siglo xvII por descendientes de vecinos de Gibraitar instalados en el barrio de San Martin y que junto a otros convecinos habían erigido un retablo en honor de su Patrona en la actual Plaza de Europa. Su instituto primordial consistente en la consolidación de la devoción y cuidado del retablo, se modificó notablemente con el fenómeno rosariano, organizando un cortejo propio que trajo consigo una gran vitalidad a la Hermandad, que amplió el retabio con obra de fábrica, adquirió una imagen de talla y un local para las insignias del Rosario. Tras una etapa de esplendor en el siglo xVIII, decayó en los primeros años del $x \mid x, y$ aunque se refundó en 1849 no tardó en extinguirse en torno a 1870.

8 La capilla del barrio de los Humeros se culmina en 1761 después de un largo periodo de obras debido a las dificultades de financiación. La de la Resolana es, en realidad, una ampliación y reforma del humilladero o capilla de la Santa Cruz, propiedad de una humilde hermandad con la que se fusionó. Se constata el inicio de estas obras en 1745, época muy floreciente en esta Hermandad. Sobre la primera Hermandad, vid mi monografia El Rosario de los Humeros. Estudio histórico-patrimonial de la Hermandad de Nuestra Señora del Rosario y Santo Cristo de la Paz. Sevilla, 1993. 
La construcción de una capilla propia significaba para la religiosidad de un barrio una autoafirmación de su personalidad, la similitud con otras formas de religiosidad "oficial» y ese afán emulador de dotar a su imagen titular de una sede tan digna como otras imágenes de la parroquia. No obstante, otras hermandades claramente vecinales como las de la Costanilla del Salvador y la Europa permanecieron en su retablo, aunque un tanto modificado y con diversos locales accesorios. Caso distinto fue el de la Cestería, cuya Hermandad se planteó trasladar su sede a un local cercano y la vecindad se negó rotundamente, entablándose incluso un pleito ante la Autoridad Eclesiástica en donde ambas partes se constituían en garantes de la devoción popular. En esta ocasión, el pretendido traslado de la sede, fallido a la postre, denota una falta de entendimiento entre la hermandad, que surge del vecindario y éste debido a una serie de circunstancias. La Hermandad se habia ido circunscribiendo a una élite minoritaria que monopolizaba la corporación prescindiendo de los cabildos generales para tomar los acuerdos ${ }^{9}$.

Precisamente en relación con esta Hermandad puede documentarse esta evolución institucional derivada de unos nuevos planteamientos socioreligiosos con respecto a la sede ya en la primera mitad del siglo XIX y, por otro lado, el arraigo geográfico de la devoción en un barrio concreto y la imposibilidad fáctica de trasladar la imagen titular a otro santuario, aunque este se hallase a pocos metros del anterior. Bastaba para dificultarlo el que se hallase en otra demarcación vecinal.

En 1829 la Hermandad de la Cestería ha evolucionado claramente en su fin institucional ya se iba produciendo y, con ella, la atención fundamental al culto de la imagen de la Virgen del Rosario, cuando la práctica rosariana estaba decayendo. En estas circunstancias, su ubicación precaria constituía un trastorno para el vecindario. Ya se había suprimido el primitivo retablo, seguramente por ampliación de la red viaria y la exposición de la imagen en un lugar abierto, además, no se conformaba con el nuevo sentimiento devocional estático, una vez desaparecido el Rosario, por un lado y aumentado, por otro, el tráfico vial que no hacían posible como antes que la calle fuera un lugar de encuentro sosegado con la imagen, además de las posibles irreverencias en un momento en que comienza a resquebrajarse la cristiandad barroca.. Lo que el vecindario unos

9 ARCHIVO PALACIO ARZOBISPAL (APA), Expediente formado por cofrades y vecinos contra los oficiales de la Hermandad, 1759, leg. 24 hdades. La operación había sido preparada poco a pocr y en secreto por el propio Alcalde de la Hermandad, habiendo cerrado el retablo callejero y trasladando diversos enseres e insignias, aunque todavía no la imagen titular, a una especie de local acondicionado como capilla en unas casas alquiladas, y se estaba pendiente de la licencia de obras. 
años antes veía como un desarraigo y un atentado contra la práctica devocional, ahora lo solicita: una sede estable y cerrada ${ }^{10}$.

El tenor de los cofrades decía así:

[...] pero ve con dolor al mismo tiempo que el local donde están colocadas las imágenes no es decoroso, pues se reduce a el zaguan de una casa, ni puede contener a los muchos fieles que concurren a orar con frecuencia y más especialmente en los dias en que se celebran funciones solemnes, viéndose obligados a permanecer en la calle donde el tránsito continuo de gente, carruajes y caballerias los distrae y hace perder el fruto que intentan sacar de su loable intención. Por otra parte, las mismas imágenes están expuestas a irreverencias y los sagrados oficios no son tan respetados como debieran a causa de la proximidad a la calle pública [...]

Así pues, con una sede inestable -en régimen de arriendo- y con estos inconvenientes, se solicita a la Jerarquía el traslado de imágenes y enseres a la vecina capilla del Baratillo, ala sazón con un culto precario limitado a los días de precepto, haciendo constar el apoyo de los vecinos de ambos barrios ante la expectativa de una mayor vitalidad de la capilla, atendida sólo por un capiller de cuya gestión el Arzobispado no estaba muy conforme. Se pide informe al cura de la parroquia del Sagrario que lo hace favorablemente, aunque previene que es necesario un acuerdo de la Hermandad con el capiller a fin de salvaguardar los derechos de los vecinos de la Cestería respecto a los cultos y sufragios.

Se accede pues, al traslado, pero entonces surge la negativa del capiller Zayas que afirma que el vecindario del Baratillo es contrario al traslado, erigiéndose en portavoz del mismo, promoviendo una instancia con la firma de varios vecinos en las que niegan que los cultos de la capilla sean escasos, dicen que es la capilla del barrio y lo ha sido desde época muy lejana y que vivían tranquilos hasta que la Hermandad del Rosario empezó a intrigar, aprovechándose de su buena fe y llegan a prevenir que si se autoriza el traslado en firme, se producirán graves conflictos, añadiendo que los oficiales de la Cestería contaban con diversas posibilidades de resolver sus problemas sin tener que trasladarse a la capilla de su barrio.

Es más. En su afán por impedir este traslado y salvaguardar la autonomía "espiritual" del barrio habían promovido un tanto subrepticiamente la restauración de una congregación existente en la capilla, solicitando

10 APA, Ramo del expediente seguido por $M$. de Zayas en 1813 sobre obtener el título de capiller de la ermita de la Virgen de la Piedad, leg. 10 hdades. 
aprobación de Reglas. Junto a estas razones abiertamente manifestadas, estaba el interés personal del capiller Zayas que se hallaba en una situación precaria al no estar conforme el Arzobispado de su gestión económica y peligrar su continuidad en el cargo. En esta tesitura, no dudó en utilizar a un grupo de vecinos no sólo ya para impedir el traslado de una hermandad foránea alegando razones devocionales, sino que fomentó la restauración de una congregación para perpetuarse así en el cuidado de la capilla y a resguardo de responsabilidades.

Estas razones ocultas fueron investigadas por el Fiscal del Arzobispado que se ocupó de este caso. De hecho, en la solicitud de traslado de la Hermandad de la Cestería había un número de firmas de vecinos del $\mathrm{Ba}$ ratillo, más o menos las mismas que las promovidas por Zayas en contra.

El Fiscal termina recomendando el traslado, aunque establece un reglamento al que tendrá que amoldarse la Hermandad de la Cestería para residir en la capilla del Baratillo, entre los que caben destacar la imposibilidad legal de derecho alguno de propiedad de la capilla, que pertenece al Arzobispado. Por otro lado, las imágenes no podrán situarse en el altar mayor. Asimismo en las funciones, tendrán preferencia las que organicen los vecinos del Baratillo. Por último, los gastos de mantenimiento se sufragarán a partes iguales.

A pesar de la aprobación jerárquica, el traslado no tuvo efecto. Los vecinos del Baratillo no contaban con ninguna apoyatura legal. Igualmente se evidenciaron unos indicios de mala fe e intereses personales entre ellos, pero prevaleció ese derecho indemostrable, pero efectivo del sentimiento devocional de exclusivismo local que hacia posible que un vecindario se constituyese en el depositario de una religiosidad popular. La capilla contaba con escaso culto, pero se revitalizó a partir de estas iniciativas. Frente a esto, la Autoridad Eclesiástica comprendió la realidad de previsibles conflictos y optó con acierto por una pastoral de cautela aunque en teoría la iniciativa del traslado era la más acertada y la que podía constituir un mayor beneficio espiritual para ambos vecindarios. Pero la lógica no tenía cabida ante sentimientos encontrados.

La Hermandad de la Cestería tampoco insistió. Encontró una rápida solución a su problema labrando una capilla de nueva factura merced ai patrocinio de un particular, con lo cual no se vio alterada la geografía devocional ${ }^{11}$.

La nueva capilla fue bendecida en 1843. Según mis investigaciones, el patrocinador fue Emilio López Dupuig, nombre que consta en un impreso suelto de indulgencias concedido a los devotos de esta hermandad de esta misma época. Sobre esta capilla, vid. Gonzalez de LEón, Noticia artística de Sevilla... Sevilla, 1844, p. 569. 
El prolongado pleito del Baratillo les hizo ver sin duda que había que buscar una opción más adecuada pues el traslado, solución apropiada en una coyuntura negativa para la capilla del Baratillo, presentaba unas perspectivas poco halagüeñas para la Hermandad, aun en el caso de que finalmente se hubiera llevado a cabo. Los vecindarios no parecían estar maduros para convivir compartiendo sus devociones.

Así pues, el barrio se nos presenta como cuna y sede que hace nacer un fenómeno concreto de religiosidad popular y que vive a diario su progreso y consolidación desde su propio entorno geográfico y humano, sintiéndolo un patrimonio propio y sobretodo un medio familiar de encuentro con la Trascendencia que cristaliza en la devoción local a la Virgen, cuya imagen vive con ellos y los patrocina. En este sentido, la sede de la Hermandad pasa de ser un mero retablo con un lienzo o Simpecado representando a la Virgen como punto de encuentro del Rosario a constituirse después y juntamente a constituirse en un santuario con una imagen concreta realizada en madera, que alimenta el sentimiento devoto del vecindario. Este santuario podrá seguir siendo el mismo retablo o se erigirá una capilla. El barrio seguirá siendo cuna y sede de la religiosidad popular mientras se viva la sintonía cotidiana y dinámica de una religión consustancial a la vida de los vecinos y que se mantendrá de modo general en los casos estudiados hasta la segunda mitad del siglo XIX.

Cabe igualmente decir que, una vez consolidada la devoción y creada la Hermandad, ésta tenía obligación de celebrar una Función anual a la Virgen, la que se llevaba a cabo en el propio entorno del retablo. Así es constatable en el caso de la Cestería o la Europa, que desarrollaba un amplio aparato constructivo efimero para tal ocasión que llegó a pervivir hasta la segunda mitad del siglo XIX, aunque en este caso lo que se desarrollaba en la plaza era el triduo preparatorio pues la Función tenía lugar en la vecina parroquia de San Martín.

\section{SENTIMIENTO DEVOCIONAL Y CONCIENCIA DE UNIDAD SOCIAL}

Ya he apuntado anteriormente como el fenómeno rosariano evoluciona paulatinamente desde una práctica oracional dinámica con cierta capacidad de abstracción a un sentimiento devocional a una imagen concreta que genera un culto diario y un patrocinio en el barrio que se concretará fundamentalmente en el siglo XIX al desaparecer definitivamente los Rosarios públicos.

No cabe duda de que el Rosario público con sus elementos de dinamismo y cotidianidad despertó una conciencia de unidad social en los ba- 
rrios a estudio: Humeros, Resolana, Cestería, Salvador, Alameda, algunos como el de los Humeros de la más humilde extracción socio-económica y marginal a la ciudad, como una especie de submundo relacionado con la actividad portuaria. La reunión diaria, a la salida del trabajo, de aquellos hombres quemados por el esfuerzo, hubo de incidir en una incipiente concienciación social volcada en torno a la religión y de una manera espontánea y, sobretodo dinámica.

Conforme el Rosario público va dejando paso al culto y devoción a una imagen concreta, de alguna manera vuelve un cierto estatismo a aquella primitiva religiosidad popular. A la Virgen no se la acerca ya a las casas a diario, no se la ve presente de alguna manera en aquellos coros de voces que la alaban con letras populares, sino que al constituir la imagen el centro absoluto de la religiosidad, ésta pierde su actividad dinámica. A la imagen se la instala en un santuario y se vuelve a la devoción anterior estática y un tanto cerrada al erigirse ya por los propios vecinos capillas, lo que constituye de alguna manera un desarraigo y despersonalización. El barrio, como centro vital, ya no puede sentir el mismo tipo de conciencia de unión social que se circunscribe a una fechas muy concretas en que tiene efecto las Fiestas de la Virgen. Ciertamente la imagen es la Patrona, pero se ha perdido en gran parte esa cotidianidad de los Rosarios y con ella la vitalidad social y el encuentro familiar con la religión que se limita a una minoría o a la ya comentada Fiesta.

Ciertamente esta evolución devocional responde a las circunstancias históricas y mentales de la época, una vez agotado el fenómeno de los Rosarios públicos. La vecindad mantiene esa primitiva religiosidad que ha forjado y la adapta a estas nuevas circunstancias. El barrio sigue vinculado a ese tipo de religiosidad y en ese sentido las Fiestas de la Virgen todavía vive esa unidad que hace posible que aunque la religión ha vuelto de nuevo a los templos, permanezca todavía presente en la conciencia histórica del barrio identificada con la imagen de su devoción.

\section{ESPONTANEIDAD Y HETERODOXIA}

Algo sustancial que el barrio aportó a la religiosidad barroca fue, sin duda, la espontaneidad de sus manifestaciones que, en muchas ocasiones promovidas por el clero regular o secular, pronto las asumió como suyas. El fenómeno rosariano gozaba ampliamente de esta cualidad y esto incluso en cortejos parroquiales o conventuales y continuó cuando se crearon las primeras hermandades rosarianas. 
La hermandad extraparroquial se sitúa en el difícil equilibrio de su arraigo e identificación con la religiosidad del barrio y su condición de ente eclesial dependiente jurídicamente de la Jerarquía, con el agravante generalizado de la incomprensión e incluso recelo de ésta ante este tipo de hermandades.

Si a todo ello se le une la escasa instrucción doctrinal y cultural de estos cofrades y vecinos es fácilmente asumible la existencia de cuestiones puntuales de heterodoxia, más bien heteropraxis sin mayor relevancia, aunque significativas y en donde se constata la incidencia del barrio en el actuar de los cofrades de la hermandad.

Cuando la Hermandad del Rosario de los Humeros buscaba fondos entre el vecindario para construir una capilla propia a mediados del siglo XVIII, su Mayordomo no reparó en medios para conseguir sus fines. Así, no tuvo inconveniente alguno en realizar ficciones de milagros que atribuía a la Virgen titular, allegando de esta manera más recursos. La Hermandad consiguió su objetivo, pero el Mayordomo sufrió duras amonestaciones, reclusión en un hospicio y posteriormente un destierro ${ }^{12}$.

En otras ocasiones, los cofrades prescindían en la práctica de sus Reglas para la celebración de ejercicios o cultos no especificados en las mismas.

Pero también se llegaba en el propio seno de las hermandades a tales escándalos, impropios de una asociación religiosa, que la Autoridad Eclesiástica debía recurrir a la excomunión incluso para poder detener los abusos que se producían. Así vino a ocurrir en la Hermandad de la Cestería cuando es electo un nuevo Mayordomo y se produce una reacción por parte de algunos oficiales, incluso por el Alcalde negándose a la reglamentaria entrega de los bienes a fin de registrarlos y depositarlo en las arcas de la Hermandad, que desemboca en la intervención de la Autoridad Eclesiástica que excomulga al anterior Mayordomo que, rápidamente rectifica su conducta, aunque con muchos recelos. En este caso, la heterodoxia se une a un auténtico escándalo entre el vecindario

12 Baquero, Francisco de Paula, Carta apologética. Respuesta al señor D. José López Herreros del Consejo de S.M., con el motivo de volver a dicho señor la tercera parte de la colección de Ideas Elementales de Educación. Sevilla, 1784. Miguel Liñán fue un ciaro exponente de una devcción espontánea, pero inculta que no apercibia contradicción entre los medios y los fines. Pero tenía otro gran defecto y es que quiso absolutizar su gobierno en la Hermandad, creyéndose el dueño de la capilla hasta el extremo de utilizarla, al parecer, para su beneficio personal y en contra de los intereses del barrio y la Hermandad. Su celo devocional desmesurado y egoista le condujo al obligado abandono de aquello en lo que habia puesto tanto empeño. 
y cofrades que va a desembocar en el aislamiento de los oficiales respecto al barrio ${ }^{13}$.

\section{EL BARRIO Y LA PRÁCTICA ASISTENCIAL DE LA HERMANDAD}

La práctica asistencial, fundamentalmente referida a los sufragios por los difuntos, era en un primer momento un instituto primordial en la Hermandad y, de hecho, un factor muy importante para la constitución jurídica de la primitiva congregación de vecinos. Así en las Reglas fundacionales de la Cestería se expresa claramente en su preámbulo que " [...] para bien y sufragio de todos los pobres deste Barrio de la Sexteria extramuros desta Ciudad de Sevilla collacion de Santa María Magdalena nos ofrecemos y dedicamos a fundar una Hermandad[... $]^{14}$.

En el contexto de la época era muy importante la asistencia espiritual después de la muerte con objeto de alcanzar mediante una ayuda o "sufragio" la salvación eterna para su alma. La Hermandad garantizaba este auxilio a sus cofrades con un ritual marcado consistente en la disposición de un aparato mortuorio con paño y cirios, acompañamiento del cadáver, aplicación de un novenario en el Rosario público y un número concreto de misas de sufragio, amén de las honras fúnebres anuales que se aplicaban a la totalidad de los cofrades. El único requisito que se exigia era la pertenencia o agregación a la Hermandad y el abono puntual de las cuotas 0 averiguaciones ${ }^{15}$.

En la Hermandad de la Costanilla del Salvador esta asistencia incluía el propio enterramiento al menos en los primeros momentos y no se limitaba a los cofrades, sino que su celo se extendía a los vecinos que fallecían sin recursos, a los que inscribían de manera poco ortodoxa como cofrades a fin de que legalmente pudiesen darle esta asistencia. Esto suponía un desembolso adicional para la Hermandad que hacía peligrar su economía y que fue denunciado ante la Autoridad Eclesiástica, pero es un ejemplo no

13 APA, Autos del Mayordomo Juan Garvallido contra el anterior Mayordomo de la Hermandad. 1751 y también: Pleito del Alcalde Juan Catalán contra el Mayordomo Carvallido por presuntas irregularidades. $1752 \mathrm{leg} .52$ hdades.

Estas continuas disputas y la incapacidad de resolverlas sin recurrir a la Autoridad Eclesiástica denotan una gravísima crisis de Hermandad que culminará con el asunto del traslado frustrado por el propio vecindario, ya referido en el primer apartado de este artículo.

14 APA, Reglas de la Hermandad de San Román y Nuestra Señora del Rosario sita en la Cesteria, 1722, leg. 24 hdades.

15 Sobre todo lo relacionado con los sufragios en estas hermandades, vid. capitulo correspondiente en mi tesis doctoral ya citada El Rosario en Sevilla..., pp. 78-81. 
infrecuente de unión con el vecindario a costa incluso de la propia supervivencia de la Hermandad ${ }^{16}$.

Esta práctica asistencial constituía un fuerte asidero del barrio con la hermandad y, por ende, con la religiosidad y la práctica concreta del Rosario que, como queda indicado, tenía un protagonismo en los sufragios por los difuntos pues, además del novenario que se le aplicaba, la propia procesión acudía al domicilio del fallecido y se le dedicaba un solemne responso. de esta manera, la hermandad estaba presente en este momento crucial de la existencia vital de los vecinos y se afianzaba más esa cercanía de lo trascendente en su propio ámbito local como un complemento afectivo a los sacramentos.

Esta práctica institucional fue decayendo como primordial en la Hermandad durante el siglo xix $y$, aunque se mantenía el sufragio por los difuntos solía generalizarse y se obviaba el acompañamiento a los entierros y el sepelio, al dictarse las nuevas normas sobre estas cuestiones y desaparecer los cementerios parroquiales y crearse uno nuevo extramuros de la ciudad. No obstante esto, en la Cestería todavía se constata como a finales de este siglo, todavía se enterraban cadáveres de vecinos de la collación en la propia capilla, aunque de manera ilegal, denunciándose el hecho ${ }^{17}$.

\section{LAS DEMARCACIONES DE RELIGIOSIDAD ENTRE BARRIOS}

Los rosarios públicos fueron marcando una especie de zonas de influencia concreta que, conforme se fueron consolidando los cortejos, solían coincidir con barrios o arrabales, aunque algunos ya contaban con un santuario devocional que lo conformaba religiosamente. Entre los barrios limítrofes existía algún tipo de relación en torno a estos Rosarios por cuanto se establecian en las estaciones diarias el paso por una o varias sedes de los rosarios limítrofes o bien capillas o santuarios de devoción, que va a pervivir posteriormente cuando las hermandades rosarianas se centren en el culto interno y durante la procesión anual de su imagen sean acompañados por representaciones de las corporaciones vecinales de los alre-

\footnotetext{
16 APA, Expediente sobre irregularidades en la recepción de hermanos en la Hermandad de la Costanilla del Salvador, 1684, leg. 64 hdades del Salvador.

El demandante fue el propio Mayordomo, lo que indica una fuerte disensión en el gobierno de la Hermandad.

17 APA, Expediente formado por el Mayordomo de la Hermandad del Rosario de la Cesteria sobre desistir de sus funcione, 1877 , leg. 32 hdades.
} 
dedores. Estos encuentros entre rosarios generaban todo un ceremonial de expresión de amistad y unión, aunque también fue origen de pleitos y enfrentamiento entre vecinos sobretodo en lo referente a la preeminencia de paso de los cortejos por un determinado lugar ${ }^{18}$.

En este apartado hay que mencionar también el caso ya indicado de la capilla del Baratillo, que ciertamente se trata de algo extremo, aunque significativo.

\section{LA PROGRESIVA DESVINCULACIÓN RELIGIOSIDAD-BARRIO}

Cuando aqui me refiero a la vinculación del barrio respecto a la religiosidad popular, lo hago fundamentalmente en términos activos, dinámicos y tangibles materialmente y no a la pervivencia en la memoria histórica, término un tanto manido por algunos autores que quieren seguir viendo incluso hoy una vinculación de determinados barrios históricos con hermandades situadas en su entorno cuando el propio concepto de barrio ya no existe como unión de vecinos, que es meramente circunstancial.

No cabe duda que la despersonalización de los barrios ha supuesto en la actualidad la desvinculación real con una religiosidad popular que propiamente se inició en su entorno y promovida por los vecinos.

Pero en este artículo me voy a referir a causas concretas documentadas en las hermandades a estudio y cuyos factores son muy variados, pero en definitiva es claro que la unión se pierde cuando la hermandad es incapaz de mantener el difícil equilibrio entre la religiosidad vecinal, a cuya iniciativa surgió y la propia dinámica de la corporación bien por alejarse del sentir del barrio de una manera progresiva y casi inconsciente, bien por la intromisión de elementos externos.

El principal factor de desarraigo fue sin duda la desaparición del Rosario callejero, como ya apunté anteriormente, a finales del siglo XVIII o primera mitad del $x \mid x$ al apercibirse tanto vecinos como cofrades que resultaba una práctica ya carente de sentido, no movía la devoción y se

18 Vid. nota 12. Francisco de P. Baquero, cura más antiguo del Sagrario, dio a luz la obra ya indicada y Panoplia sagrada (1786) en las que criticaba negativamente los usos de la religiosidad popular, en especial los Rosarios. Frente a él, surgió Antonio de Vargas, cura de la Magdalena, argumentando sus grandes valores en sus obras Reflexiones cristianas (1785) y Carta Instructiva (1786). Supone una interesante documentación este intercambio de argumentos sobre la religiosidad popular en urıa época tan crítica como la de finales del siglo xvil.. 
prestaba a abusos. Continuaba con fuerza la devoción a la imagen titular de la hermandad, pero había desaparecido la razón fundacional de aquel movimiento de religiosidad cotidiano. Se abría el horizonte mental de los sevillanos y la religión iba volviendo de nuevo a los templos, aunque estos fueran erigidos como capillas propias del vecindario.

En este sentido, un factor consecuente fue la ya anunciada separación progresiva entre hermandad y vecindario motivada por el traslado a una sede propia en donde la autonomía de los cofrades era mayor respecto a la presión del vecindario, que iba perdiendo influencia y su presencia activa como tal se limitaba a las fiestas de la Virgen y la procesión por las calles. La cotidianidad devocional era de carácter opcional, entrando en un marco cerrado como el resto de los templos de la ciudad.

En las hermandades extraparroquiales a estudio se sufrió enormemente esta crisis lógica y de hecho marcó en algunas su progresiva extinción, caso de la Europa que terminó trasladándose obligada por un ensanche a la vecina parroquia de San Martín y allí concluyó totalmente. El Rosario de la Cestería entró en decadencia a finales del siglo xix y aunque permaneció la capilla, la devoción a la imagen titular y la hermandad desaparecieron ${ }^{19}$. La de la Resolana tuvo una sucesión de altibajos, pero muy separada ya del barrio y terminó uniéndose a una hermandad de penitencia ya en este siglo ${ }^{20}$. En el Rosario de los Humeros se alcanzó un notable apogeo en la segunda mitad del XIX, pero una serie de diatribas con la parroquia y una dinámica propia de pasividad, hizo posible que a principios del presente siglo, hubiera una disposición legal del Arzobispado que impuso una nueva junta de gobierno en la que se relegaba a los anteriores oficiales por una serie de irregularidades y se daba entrada a diversos cofrades ajenos al barrio que, sin embargo, promovieron un importante relanzamiento de la Hermandad y trataron de crear unas nuevas bases estructurales en las que la unión con el barrio era uno de los pilares, pero la iniciativa fue decayendo hasta desaparecer unos años después. La Hermandad ha logrado pervivir, pero separada

19 El último documento que he podido encontrar data de 1889. La capilla ha permanecido abierta al culto hasta 1961 en que fue demolida para construir una casa de pisos y la imagen titular trasladada a la parroquia de San Eugenio. No obstante, testimonios orales de vecinos de edad nos certifican la inexistencia de la hermandad como tal mucho antes de esta fecha.

20 Se constata un cierto renacimiento en la segunda década de este siglo, pero vuelve a decaer poco después. En torno a los años 50 un grupo de jóvenes intentan una revitalización, pero ya con independencia del barrio. Finalmente, con una existencia meramente formal, se fusiona con la cofradia penitencial del Cristo de las Aguas, que toma posesión así de la capilla en 1977. 
de hecho de su tradicional entorno humano, que además está casi totalmente renovado ${ }^{21}$.

Conforme, pues, se van diluyendo o cambiando de fisonomía los dos conceptos claves de religiosidad popular y de vecindario o barrio, la vinculación tiende a desaparecer, aunque la memoria histórica siga presente en la población y todavía existan ejemplos sintomáticos de la unión entre el barrio y una determinada devoción popular como puedan ser los casos de las imágenes de la Esperanza Macarena o de Triana, pero que responden a otra concepción más abierta del término de barrio que no se circunscribe al ámbito geográfico tradicional y, por otro lado, la pasividad manifiesta de éste respecto a la vida activa y efectiva de las corporaciones que cuidan de la devoción. A todo ello hay que añadir la propia significación vital de estos fenómenos de religiosidad vecinal que no responde en su mayor parte a la concepción primordial cristiana y a la convicción de una transcendencia que implica un compromiso, sino que se limita a unos sentimientos vivenciales que pueden ser profundos, pero que no implican la vida de la persona y todo eso conlleva una lógica y clara conclusión: la pérdida de personalidad de la religiosidad primitiva que nacía de una identificación compartida de valores que hacían posible la unidad en torno a una devoción o práctica devota.

La despersonalización general de la sociedad, la falta de comunicación generadora de una crisis de soledad en el hombre hacen hoy prácticamente imposible que se pueda concebir la unidad solidaria de unos barrios con marcada personalidad. Por otro lado, la constitución en gran parte de las hermandades de una superestructura permanente que controla su vida en desconexión con el cuadrante general de hermanos y aislada voluntariamente de su entorno geográfico vital -muy cambiante, por otro lado, en el casco histórico- posibilitan un tipo de religiosidad elitista que ni procede del pueblo ni está en sintonía con él, con lo que va desapareciendo su primitiva y fundamental razón de ser.

21 La Hermandad cae en una decadencia importante en la segunda década del siglo, tras una etapa interesante donde el apoyo del barrio fue decisivo para restaurar la maltrecha fábrica de la capilla. Los oficiales caen en una profunda atonía que obliga a la parroquia y Autoridad Diocesana a intervenir para preservar la legalidad jurídica, aconsejada por un grupo de cofrades interesados en el gobierno de la Hermandad, pero al que la junta le impedía el acceso al no convocar elecciones. Esto unido a un cierto enfrentamiento con la parroquia, hace que sea la propia Autoridad Diocesana la que convoque elecciones, a la que se niegan a concurrir los antiguos oficiales, por lo que el grupo de cofrades liderados por Enrique Gómez Millán accedió al gobierno. Con él comienza una nueva etapa en la Hermandad, ciertamente de mayor auge económico y cultual, pero en gran parte desarraigada de un barrio, cuyos vecinos - los antiguos oficiales lo eran- habian dejado ya languidecer la primitiva hermandad surgida en sus calles. 


\section{EPILOGO}

En definitiva, el Barroco y la llustración suponen en la religiosidad popular sevillana la época paradigmática en que se erige su estructura formal, se definen sus elementos básicos y se establece un genuino dinamismo devocional que convierte al pueblo en generador de sus propias iniciativas con prácticas concretas de religiosidad que toma como suyas, aunque no lo sean exactamente y esto a través de los vecindarios que se constituyen en patrocinadores y garantes de estas devociones, que con el tiempo adquieren una estructura eclesial formal con la constitución de hermandades.

En este artículo he tratado de mostrar que la vinculación entre el vecindario y la religiosidad popular es una tesis fundamental para la comprensión del fenómeno en los periodos descritos centrándome en el estudio de datos históricos procedentes de barrios eminentemente populares de Sevilla y de hermandades extraparroquiales, todas unidas por la práctica cotidiana de los Rosarios públicos, cuyo papel configurador de una genuina religiosidad popular es indudable.

Así se genera toda una estructura religiosa cotidiana que tiene como escenario no el recinto de $u$ templo, sino las propias calles del barrio. La religión actuaba de aglutinante social y desarrollaba unos vínculos integradores entre las gentes de un vecindario, que consolidará una marcada personalidad que se refleja muy especialmente en la vida cotidiana y de cultos externos de la Hermandad.

El vecindario, que ha hecho nacer una práctica concreta de religiosidad, tiene plena consciencia de que esta devoción supone una relación muy especial con la Transcendencia, muy enraizada en sus vidas y que la hermandad surge como ese cauce por el que puede expresar ese sentimiento profundo $y$, en este sentido, se siente responsable de su historia, incluso frente a sus cofrades de derecho y la propia Autoridad Eclesiástica.

Aunque en el siglo $x i x y$, sobre todo, el $x x$ diversas circunstancias han ido motivando un progresivo distanciamiento entre hermandades originariamente populares y su sustrato vecinal característico, la estrecha vinculación que detecta el periodo a estudio hace pervivir todavía, aunque con un sentido distinto, esa identificación y, a pesar de la evidencia de que la cotidianidad religiosa ha desaparecido, parece como si se concentrara puntualmente en determinados momentos, actualizando una cierta memoria histórica. 